\title{
ЖИЗНЕННЫЙ СЦЕНАРИЙ ЛИЧНОСТИ: НАПРАВЛЕНИЯ ИССЛЕДОВАНИЯ
}

Петросьян С.H.

Проблема жизненного сценария привлекала внимание ученых практически с самого начала возникновения психологии как самостоятельной области научного знания. Исследования жизненного сценария, его структурных компонентов, сценарного поведения были освещены в трудах 3. Фрейда, А. Адлера, К.Г Юнга, Й. Стюарта, К. Штайнера, К. Роджерса, Г. Олпорта, Б. Г. Ананьева, С. Л. Рубинштейна, К. А. Абульхановой-Славской, Л. Н. Когана, Н. В. Гришиной, В. Н. Дружинина и др.

Общим значением понятия «жизненный сценарий» является некая заданность, упорядоченность хода действий и событий (субъективно значимых ситуаций) относительно прошлого, настоящего и будущего [8].

В общей тенденции западных подходов к изучению проблемы жизненного сценария можно выделить два направления: 1) проблема сценарного (повторяющегося) поведения, 2) проблема сценарной предопределенности жизни.

Одним из первых на феномен повторяющегося поведения обратил внимание 3. Фрейд. Он заметил, что в процессе психоаналитической терапии приходится иметь дело с разнообразными проявлениями навязчивых повторений со стороны больных. Такое явление получило название «отыгрывание».

Впервые 3.Фрейду пришлось иметь дело с феноменом отыгрывания при лечении молодой девушки в 1900 году (случай Доры).

В работе «По ту сторону принципа удовольствия» (1920) 3. Фрейд отметил, что проявления навязчивого повторения, встречающиеся в психической жизни раннего детства и в случаях из психоаналитической практики, отличаются настолько непреодолимым, «демоническим» характером, что можно предположить наличие в живом организме «стремления к восстановлению какого-либо прежнего состояния».

В «Новом цикле лекций по введению в психоанализ» (1933) 3. Фрейд высказал мысль, в соответствии с которой в навязчивом повторении выражается «консервативная природа инстинктов» и оно преобладает даже над принципом удовольствия: «Есть люди, которые в своей жизни без поправок повторяют всегда именно те реакции, которые им во вред, или которых, кажется, преследует неумолимая судьба, в то время как более точное исследование показывает, что они, сами того не зная, готовят себе эту судьбу» (курсив наш) [5].

Таким образом, З.Фрейд пришел к мысли о том, что природа повторяющихся действий инстинктивна: первые сильные эмоциональные реакции индивида закрепляются в форме рефлекса, который индивид склонен воспроизводить в дальнейшей жизни, воспроизводя как эмоциональные реакции, так и тип поведения, который им соответствует. 
Второе направление (сценарной предопределенности жизни), представлено в исследованиях К.Г. Юнга и постюнгианском направлении (архетипическая психология).

К.Г. Юнг в результате многолетних клинических наблюдений пришел к заключению, что в психике человека существенную роль играет не только индивидуальное, но также и коллективное бессознательное, содержание которого представлено архетипами, унаследованными от предков. Архетипы (от греч. «архе» - «начало» и «типос» - «образ») - мощные психические первообразы, скрытые в глубинах бессознательного, изначальные модели восприятия, мышления, переживания.

Энергия архетипа инстинктивна, поскольку архетип по своей сути есть инстинкт; архетип есть "поведенческий паттерн" инстинкта, его значение или, как выразился Юнг, "его психический эквивалент" [13,5, курсив наш].

С этой позиции личность является театром архетипических фигур, часть из которых располагается на переднем плане внизу и в центре, другие ожидают за кулисами. [13,7 курсив наш].

То есть, постюнгианская психологическая традиция склонна считать, что сценарные проявления личности обусловлены архетипическими образами, и по сути инстинктивны.

Хотя феномен повторяющегося типичного поведения исследовался достаточно интенсивно, термин «сценарий» вошел в терминологический аппарат психологии сравнительно поздно. Концепция сценария была разработана Э. Берном и его коллегами, особенно К. Стайнером, в середине 60х годов. И в настоящее время она является, наряду с моделью личности, основанной на состояниях Я (эго-состояниях), центральной идеей транзактного анализа [11].

В работе «Принципы группового лечения» Берн определил жизненный сценарий как "неосознаваемый план жизни". Позже, в книге «Что вы делаете после того, как сказали «привет», он дал более полное определение: "План жизни, который составляется в детстве, подкрепляется родителями, оправдывается последующими событиями и завершается так, как было предопределено с самого начала" [1].

Согласно Э. Берну, жизненный сценарий является некоей бессознательной структурой, программой поступательного развития, управляющей жизнью человека и определяющей его поведение в важных жизненных аспектах.

Транзактные аналитики большое внимание уделяли феномену повторяющегося поведения, которое в рамках транзактного подхода получило название «сценарное поведение

Признаком сценарного поведения является определенная, зафиксированная последовательность мыслей, чувств и действий, которая воспроизводится каждый раз в неизменном виде, в одном и том же порядке. Может меняться контекст, обстоятельства и даже содержание ситуаций, но распознаваться и трактоваться личностью они будут всегда схожим образом, соответственно, и вести себя человек будет схожим способом. Каждый раз по завершении сценарного цикла (в терминологии Э. Берна) личность делает из 
состоявшегося события одни и те же выводы, подкрепляет одни и те же когнитивные и эмоциональные установки, способствуя тем самым закреплению модели сценарного поведения. Таким образом, можно говорить о некоторой устоявшейся модели поведения или схеме действий, которая воспроизводится в ряде аналогичных жизненных ситуаций.

С.П.Гурская, рассматривая феномен сценарного поведения личности, подчеркивает, что нередко непроизвольная повторяемость типичных жизненных ситуаций и проблем трактуется субъектом как неудовлетворительная, нежелательная, но неизбежная. Неизбежность повторяемости обусловлена тем, что субъект не осознает механизмы возникновения повторяющихся ситуаций, а также не находит способы сознательного контроля хода повторяющихся событий. Можно сказать, субъект не отдает себе отчет в том, по каким причинам с ним постоянно происходят одни и те же неудовлетворительные события, почему ему приходится сталкиваться с одними и теми же повторяющимися специфическими проблемами, предотвратить появление которых личность не в состоянии [3].

С позиций экзистенциального подхода человек ежедневно выбирает и подтверждает свое существование, свое бытие. Но западные исследования жизненных сценариев и сценарного поведения показывают, что природа сценарного поведения инстинктивна: независимо от контекста, обстоятельств и даже содержания ситуаций, распознаваться и трактоваться ситуация будет типичным для индивида образом. Каждый раз по завершении сценарного цикла личность делает из состоявшегося события одни и те же выводы, подкрепляет одни и те же когнитивные и эмоциональные установки, способствуя тем самым закреплению модели сценарного поведения (Э. Берн, Й. Стюарт, В. Джойнс, К.Штайнер, и др.).

В отечественной психологии, методологическим основанием которой долгое время служил деятельностный подход, сложился противоположный ракурс исследования проблемы жизненного сценария личности (Б.Г.Ананьев, С.Л.Рубинштейн, Ю.М.Резник, Н.А.Рыбников, К.А.Абульханова-Славская, А.А.Кроник, Е.И.Головаха, Н.В.Гришина, Т.С.Мороз, Н.В.Дружинин, А.В. Сохань и др.).

(Субъектно)-деятельностный подход (А.Н. Леонтьев, С.Л. Рубинштейн и др.) подразумевает, что основным атрибутом субъекта является активность: субъект «обозначает», «определяет» себя своей активностью. Такие характеристики, как жизненные цели, стратегии жизни, смысловые ориентации и др., опосредуют взаимодействие человека с миром. Согласно субъектнодеятельностному подходу, личность осознанно выбирает и регулирует процесс жизни. По выражению С.Л. Рубинштейна, «человек сам определяет свое отношение к жизни, гармонично или дисгармонично связывая между собой трагедию, драму и комедию» [Цит. по: 4].

В работах Ю. В. Синягина, О. Ю. Перевезиной, Ю. А. Яковлевой, А. В. Поляковой указывается на смысловое сходство жизненного сценария с понятиями, разработанными в отечественной психологии: «жизненный план», «жизненная стратегия», «жизненная цель», «жизненный стиль» и др. [12]. 
Данные понятия отражают российскую тенденцию, заданную трудами С.Л.Рубинштейна, Б.Г.Ананьева и др. к рассмотрению детерминант жизненного сценария личности, связанного с возможностью самоопределения и сознательного выбора личностью жизненного пути. Мизинова А.И. считает, что эти понятия являются производными от жизненного сценария и связаны с его функцией планирования - конструирования (жизненный план, жизненная цель, жизненный смысл, жизненный девиз) и структурирования жизни (при помощи жизненной стратегии, жизненного стиля) [6]. В частности, по мнению Л.А.Губаревой, направленность жизненных целей обусловлена специфическим содержанием жизненных смыслов личности, которые формируют ее жизненный девиз. Именно жизненный девиз, в представлении автора, основанный на жизненных целях и смыслах, является базисом жизненного сценария [2].

Но и в западных подходах, начиная с А. Адлера и Г. Олпорта, существуют подобные воззрения. Так, Адлер, предвосхищая положения гуманистической психологии, говорил, что в постоянном стремлении к совершенству, люди способны планировать свои действия и определять собственную судьбу. Именно выбор жизненной цели задает вектор движения и отражает отношение человека к собственной жизни [14].

В своем труде «Основные особенности психологии личности» (Becoming: Basic considerations for a psychology of personality, 1955), Олпорт писал: «Некоторые теории развития основаны, главным образом, на поведении психически нездоровых и тревожных людей или же на выходках доведенных до крайности лабораторных крыс. Очень немногие теории сформировались на основе изучения здоровых человеческих существ, таких, которые не столько стараются сохранить свою жизнь, сколько стремятся сделать ее осмысленной» $[15,180]$.

Ни Адлер, ни Олпорт, подчеркивая способность человека к свободному жизнетворчеству, не изучали проблему жизненного сценария личности. Скорее всего, в силу того, что жизненный сценарий, с их точки зрения, не является проблемой здоровой личности со здоровым и свободным целеполаганием.

И тогда мы сталкиваемся с противоречием: с одной стороны, человек творец собственной жизни, и представители психологической науки, которые придерживаются такой точки зрения, практически с отвращением говорят о предопределенности и неотвратимости разворачивания жизненного сценария.

С другой стороны, мы имеем доказательства обратного. В многочисленных исследованиях, посвященных проблеме жизненных сценариев личности, неоднократно подчеркивалось, что жизненный сценарий личности не всегда обусловлен сознательным выбором человека (Ф.Перлз, А.А. Шутценбергер, С. Гроф и др.), и наиболее полно и четко рисунок жизненного сценария личности проявляет себя в условиях переживания кризиса либо нахождения в нестандартных ситуациях.

Принципиальная новизна личностно-бытийного подхода (3.И. Рябикина) заключается в том, что основным механизмом, детерминирующим развитие психики выдвигается не противоречие «индивид - среда», или «личность - 
среда», предполагающая некое третье опосредующее звено, например личность - (деятельность) - среда, или, личность - (система когниций) - среда (характерное для российских и западных исследований личности предыдущего этапа); а взаимообусловленная дуальность «личность и ее бытие» [9;10].

Рассмотрение в качестве предметной области психологии категориальной целостности «личность и её бытие» (З.И.Рябикина) создают возможность принципиально нового подхода к изучению проблемы формирования и реализации жизненного сценария личности.

Если рассматривать динамику возрастного развития с точки зрения расширения бытийности личности по мере прохождения стадий развития, в таком развитии личность осваивает позиции в отношениях Я - Мир (досознательный уровень, базовое доверие - недоверие к Миру), Я - Ты (предсоснательный уровень, доверие - недоверие к Другому), Я - Они (сознательный уровень, доверие - недоверие к социуму). По мере прохождения стадий развития личностью осваиваются различные позиции в отношениях доминантная, пассивная, либо здоровая, адекватная теме возраста. Такие позиции встраиваются в структуру личности, и впоследствии на правах значимых частей личности начинают экспансироваться во внешнее пространство, организуя бытие согласно своим смыслам.

3.И.Рябикиной [9;10] предлагается рассмотрение личности как реализующей в своем поведении три сопряженные базовые потребности: (a) потребность в самоактуализации, в экспансии, (б) потребность во внутренней согласованности и сохранении целостности психического, (в) потребность быть подтвержденной внешним, тем, через что объективировано ее субъективновнутреннее (потребность в обретении и поддержании целостности внешнего и внутреннего, объективного и субъективного пространств личности).

Эти три потребности могут рассматриваться как: (а) потребность реализовать позицию, занимаемую в отношениях Я - Мир, Я - Ты, Я - Они, (б) потребность сохранять устойчивость такой позиции, (в) потребность организации жизненного сценария таким образом, чтобы он, людьми и событиями, вовлеченные в него, подтверждал позицию в отношениях Я - Мир, Я - Ты, Я - Они [7].

Причем позиция в отношениях, согласно личностно-бытийному подходу (3.И. Рябикина), как часть структуры личности детерминирует процесс отражения реальности и распредмечивает действительность в соответствии со своими целями, запросами и потребностями.

Таким образом, жизненный сценарий является глобальным бытийным пространством личности и одним из способов выражения интенции БЫТЬ, т.е. поддерживать и расширять свое бытие.

Рассмотрение личности и ее бытия как категориальной целостности (3.И. Рябикина) создает возможность не только объединения противоречивых теоретических подходов к исследованию жизненного сценария, но имеет большой практический потенциал с точки зрения диагностики, прогнозирования и коррекции важнейших жизненных ситуаций и возможных линий развития жизненного сценария личности. 


\section{Литература}

1. Берн Э. Игры, в которые играют люди. -Екатеринбург: Литур, 2001. $576 \mathrm{c}$.

2. Губарева Л. А. Зависимость ведущего сценария от отношения к смерти // Проблемы здоровья личности в теоретической и прикладной психологии: материалы междунар. науч.-практ. конф. / под ред. Н. А. Кравцовой. Владивосток, 2011. С. 104-111.

3. Гурская С.П. Программа сценарного поведения // Вестник ЮУрГУ. Серия «Психология», 2013, том 6, № 1. / С. $101-104$.

4. Дружинин В.Н. (ред.) Психология /Учебник для гуманитарных вузов // / 16.4. Жизненные планы и жизненный сценарий. - Спб: Издательский дом «Питер», 2001. [URL: http://www.bibliotekar.ru/psihologia-2/152.htm].

5. Лейбин В. Словарь-справочник по психоанализу. М., «ФСТ Москва», 2010.

6. Мизинова А.И. Жизненные сценарии личности: основные подходы к рассмотрению // Известия Саратовского ун-та. Нов. серия. Сер. Философия. Психология. Педагогика. 2013. Т. 13. , вып. 4. С. 69-54.

7. Петросьян С. Н. Перспективы исследования жизненного сценария личности в русле субъектно-бытийного подхода / Научно-информационный журнал Человек. Сообщество. Управление. 2016. Том 17. №2. С. 6-25.

8. Пряжников Н. С. Профессиональное самоопределение: теория и практика. М.: Академия, 2007. -189с.

9. Рябикина 3.И. Бытийный подход к рассмотрению личности и личностный подход к рассмотрению бытия // Психология личности её бытия: теория, исследования, практика / Под ред. 3. И. Рябикиной, А.Н. Кимберга, С.Д. Некрасова. Краснодар: Кубанский гос. ун-т, 2005. - C.10-36. [URL: http://reftrend.ru $937916 . h t m l]$.

10. Рябикина 3.И. Личность как субъект формирования бытийных пространств // Субъект, личность и психология человеческого бытия DJVU / Коллективная монография /Под ред. В.В. Знакова, З.И. Рябикиной. - М.: Изд-во "Институт психологии РАН", 2005. С. 45-58.

11. Стюарт Й. Современный транзактный анализ / Й. Стюарт, В. Джойнс . - СПб.: Социально-психологический центр, 1996. - 329 с.

12. Синягин Ю. В., Переверзина О. Ю., Яковлева Ю.А., Полякова А.В. Основные подходы к исследованию жизненных стратегий личности // Акмеология. 2010. № 1. С. 27-34.

13. Хиллман Дж. "Архитепическая психология" // Изд.: Б.С.К., 1996. 157c. // [URL: dic.academic.ru>dic.nsf/ruwiki/322073].

14. Хьелл Л., Зиглер Д. Теории личности / Основные положения, исследования и применение / Перевод С.Меленевской и Д.Викторовой. -СПб.: Питер Пресс, 1997. -608c.

15. Allport. G.W. Becoming: Basic considerations for a psychology of personality/ New Havan, CT: Yale University Press, 1955. 